\title{
ヒト気道上皮細胞におけるペリオスチン産生の検討
}

\author{
洲崎 勲夫 ${ }^{1,2}$, 田名部 毅 ${ }^{2,3}$, 浅野 和仁 ${ }^{4}$, 水吉 朋美 ${ }^{1}$, \\ 渡邊＼cjkstart荘 ${ }^{1,5}$, 小林 一女 ${ }^{1}$, Bruce $\mathrm{K}$ Rubin ${ }^{2}$ \\ 1 昭和大学医学部耳鼻咽喉科学講座 \\ ${ }^{2}$ Department of Pediatrics, Virginia Commonwealth University School of Medicine \\ ${ }^{3}$ 長野県信濃町立信越病院 \\ 4 昭和大学保健医療学部生理学研究室 \\ ${ }^{5}$ 国立国際医療センター国府台病院
}

\section{Periostin production from human bronchial epithelial cells}

\author{
Isao Suzaki ${ }^{1,2}$, Tsuyoshi Tanabe ${ }^{2,3}$, Kazuhito Asano ${ }^{4}$, Tomomi Mizuyoshi ${ }^{1}$, \\ So Watanabe ${ }^{1,5}$, Hitome Kobayashi ${ }^{1}$, Bruce K Rubin ${ }^{2}$ \\ ${ }^{1}$ Department of Otorhinolaryngology, School of Medicine, Showa University \\ ${ }^{2}$ Department of Pediatrics, Virginia Commonwealth University School of Medicine \\ ${ }^{3}$ Shinano Municipal Shinnetsu Hospital \\ ${ }^{4}$ Division of Physiology, School of Nursing and Rehabilitation Sciences, Showa University \\ ${ }^{5}$ Kohnodai Hospital, National Center of Global Health and Medicine
}

\section{1.はじめに}

ペリオスチンは細胞外マトリックス構成タンパク質と接 着することによる組織構築の維持や線維化における役割と ともに，細胞表面のインテグリン分子を受容体として細胞 に作用し, 好酸球の誘導や粘液産生の増強等, アレルギー 性炎症に関与する分子量約 90-kDa のタンパク質とされて いる1)。ペリオスチンはTH2 サイトカインである IL-4 や IL-13の刺激により気道線維芽細胞や気道上皮細胞より分 泌され，重症喘息患者の気道上皮では強く発現している事 が報告されている ${ }^{1,2)}$

気道において，ペリオスチンは線維芽細胞よりの産生の 検討は幾つか報告があるものの, 上皮細胞を用いたペリオ スチンの分泌・産生のメカニズムについてはまだ十分に検 討がされていない。今回我々は, ヒト正常気道上皮細胞 (Normal human bronchial epithelial cells: NHBEc) を Air liquid interface: ALI 法を用いて培養・分化した細胞を用いて, IL-13の刺激により誘導されるペリオスチンの産生・放出 機構について検討した。

\section{2. 方法}

\section{1）細胞培養}

NHBEcはLonza社より購入した。液体窒素で保存し，3代 継代したNHBEcを, ラット II 型コラーゲンで処理した, 直
径 $6.5 \mathrm{~mm}$ のトランスウェルに，それぞれ $1.0 \times 10^{6} \mathrm{cell} / \mathrm{s} / \mathrm{mL}$ の密度で播種した。線毛上皮細胞への分化へ用いた分化 誘導用培地は, DMEM 培地とF-12 培地を $1: 1$ で混合した 細胞培養用培地に $0.5 \mathrm{ng} / \mathrm{mL}$ 上皮成長因子, $1 \%$ InsulinTransferrin-Selenium-A, $30 \mu \mathrm{g} / \mathrm{mL}$ ウシ下垂体抽出物, $1.0 \times$ $10^{7} \mathrm{M} レ$ チノイン酸, $2.0 \mu \mathrm{g} / \mathrm{mL}$ ウシ血清アルブミン,

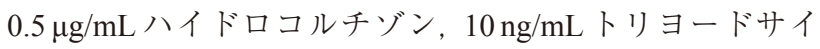
ロニンを添加したものを用いた。IL-13 誘起性杯細胞への 分化誘導へは, 前述の分化誘導用培地へ IL-13 $10 \mathrm{ng} / \mathrm{mL}$ を 添加したものを用いた。NHBEc は3 日間液相培養した後, 上部 (管腔側) の培地を吸引し, ALI 法にて計 14 日間気相 培養した。培養第 15 日目に各々の細胞群をPBS 添加した 分化誘導用培地で 24 時間培養する事で, IL-13の影響を除 去した。各々の細胞群を16日目に IL-13 (10 ng/mL)によ る刺激を基底膜側から行った。刺激後 72 時間後に基底膜 側の培地・管腔側の上清の回収を行った。
2) ペリオスチンタンパクの測定
培地中・上清中のペリオスチンは human periostin/OSF-2 ELISA キットを用いて測定した。

\section{3. 結果}

1）線毛上皮細胞と IL-13 誘起性杯細胞

NHBEcを 14 日間気相培養を行う事で, 管腔側へ線毛を 
線毛上皮細胞

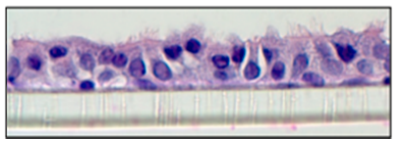

図 1 線毛上皮細胞と IL-13 誘起性杯細胞の病理所見

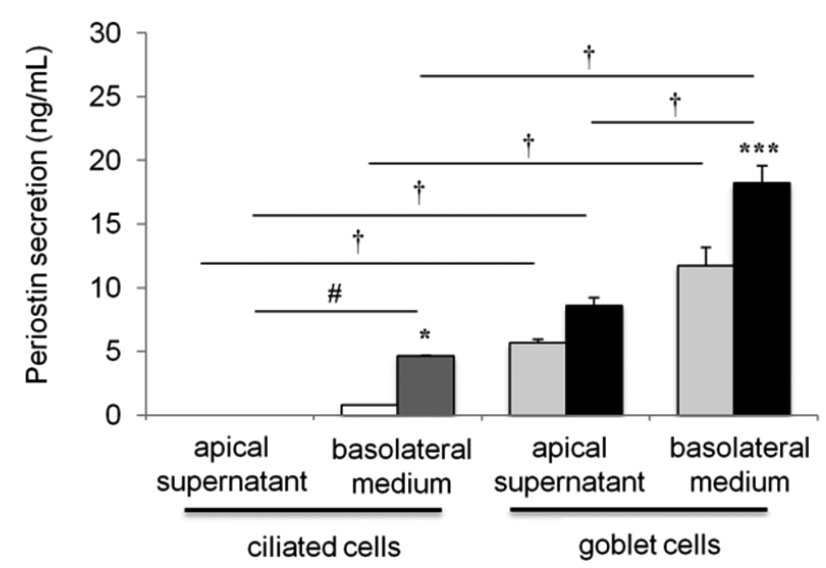

図 2 線毛上皮細胞と IL-13 誘起性杯細胞からのペリオスチン産生

有する線毛上皮細胞へと分化した。また, IL-13 添加下で気 相培養を行う事で, 核の偏在を伴う IL-13 誘起性杯細胞へ と分化が認められた（図 1)。

2) 線毛上皮細胞と IL-13 誘起性杯細胞からのペリオスチン 産生

線毛上皮細胞にIL-13 の刺激を行う事で，ペリオスチン のタンパク産生は基底膜側から検出された。一方, IL-13 誘起性杯細胞からは杯細胞からは, 基底膜側・管腔側の両 側よりペリオスチンのタンパク産生が検出された。

各々の細胞群を基底膜側より IL-13で刺激する事でペリ オスチンの産生量を比較したところ, 線毛上皮細胞に比較 して IL-13 誘起性杯細胞から管腔側・基底膜側の両側へ と,より多い量のペリオスチンの産生が認められた（図 2)。

\section{4. 考察}

本研究では, 線毛を有する細胞に分化させた気道上皮細 胞と, IL-13 で気相培養を行う事で IL-13 誘起性杯細胞へ と分化させた 2 群よりを用いて, IL-13 依存性のペリオス
チン産生の分泌・極性を検討した。ペリオスチンは線毛上 皮細胞に比較して, IL-13 誘起性杯細胞より多く産生され, 管腔側よりも基底膜側への分泌が多い結果であった。

気管支喘息患者の気道上皮と, 慢性副鼻腔炎患者の鼻 · 副鼻腔粘膜上皮には共通点が多く、リモデリングにより上 皮の杯細胞化生や基底膜肥厚, 好酸球浸潤が見られる。気 道上皮に扔いて杯細胞はMUC5ACをはじめとしたムチン やサイトカイン・ケモカイン・成長因子等を分泌し, 気道 炎症の増悪に扔いて重要な役割を担うとされる。今回の 我々の検討では，気道上皮に执いて特に杯細胞がより多く のペリオスチンを産生する事で, 粘液過分泌や好酸球炎症 の惹起, リモデリングの促進へ寄与している可能性が推察 された。

気道上皮細胞よりのペリオスチンの分泌は基底膜側への み, もしくは管腔側へのみ検出されたといった報告が混在 していた 2,3$)$ 。好酸球性炎症の強い気管支喘息患者の喀痰や 血清, 慢性副鼻腔炎患者の鼻汁や血清のペリオスチン濃度 は高值であり, 特に血清中のペリオスチンが好酸球炎症を 反映するバイオマーカーとなる事が報告されている ${ }^{1,4,5)}$ 気道上皮細胞に扔いて, 特に杯細胞が喀痰や血清中のペリ オスチンの産生源となっている可能性が示唆された。

\section{参考文献}

1) Izuhara $\mathrm{K}$, Arima $\mathrm{K}$, et al. Periostin in allergic inflammation. Allergol Int. 2014; 63: 143-51.

2) Sidhu SS, Yuan S, et al. Roles of epithelial cell-derived periostin in TGF-beta activation, collagen production, and collagen gel elasticity in asthma. Proc Natl Acad Sci USA. 2010; 107: 14170-5.

3) Mouthuy J, Viart S, et al. Mite allergen-specific $\operatorname{IgE}$ is detectable in bronchial secretions of patients with nonatopic asthma and correlates with mucosal expression of periostin. J Allergy Clin Immunol. 2015; 136: 1685-8.e1-2.

4) Ohta N, Ishida A, et al. Expressions and roles of periostin in otolaryngological diseases. Allergol Int. 2014; 63: 17180.

5) Bobolea I, Barranco P, et al. Sputum periostin in patients with different severe asthma phenotypes. Allergy. 2015; 70 : 540-6. 


\title{
第 35 回日本耳鼻咽喉科免疫アレルギー学会 奨励賞応募演題 S-2
}

\section{頭頸部癌に対する抗腫瘍ウイルス HF10 の抗腫瘍効果}

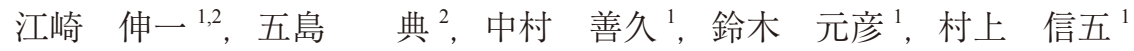 \\ ${ }^{1}$ 名古屋市立大学大学院耳鼻咽喉 $\cdot$ 頭頸部外科 \\ 2 名古屋大学大学院ウイルス学
}

近年, 癌細胞で特異的にウイルスが増殖して細胞を破壊する「腫瘍溶解ウイルス療法」が注目されてきている。我々は, 自然発生型弱毒型単純ヘルペスウイルス HF10 が安全性を保ちつつ, 多くの腫瘍細胞で抗腫瘍効果を示すことを明らかに示 してきた。現在米国にて，再発頭頸部癌等を対象に第 II 相試験を終えたところである。そこで我々はHF10の頭頸部扁平上 皮癌への抗腫瘍効果と抗腫瘍免疫の誘導につき検討した。ヒ卜扁平上皮癌細胞株（FaDu, Detroit 562）, マウス扁平上皮癌細 胞（SCC-VII）だけでなく, ヒト下咽頭癌, マウス舌癌の臨床検体から抽出された細胞株（NSCC-1F, NSCC-2F, TC4T+, TC5s）に扔いても，HF10の増殖と殺細胞性が認められた。次に SCC-VII をマウスの耳介に接種して，HF10を腫瘍内接種し たところ, 腫瘍の縮小効果を認め, 5 匹中 3 匹の腫瘍は消失した。また, 生き残ったマウスは腫瘍の再接種に抵抗した。組 織学的には HSV 感染領域に一致して腫瘍の壊死と CD8 陽性細胞を認めた。脾臟内には好中球と CD8 陽性細胞の増多を認め, その脾細胞を腫瘍細胞で刺激したところ，抗腫瘍サイトカインの分泌を認めた。以上の結果から頭頸部扁平上皮癌に対する 抗腫瘍ウイルス HF10 の抗腫瘍効果と抗腫瘍免疫の誘導が示された。 


\section{第 35 回日本耳鼻咽喉科免疫アレルギー学会 奨励賞応募演題 S-3}

\section{好酸球性炎症における気道上皮細胞と好塩基球の相互作用}

松本 晃治, 神前 英明, 清水 猛史

滋賀医科大学耳鼻咽喉科

【はじめに】好塩基球の役割については不明な点が多いが，近年，上皮細胞などから放出されるIL-33やIL-18刺激によって， Th2 サイトカイン（IL-5, IL-13, IL-4）を産生することが報告され，アレルギー性炎症に直接関わっていると考えられる。し かしながら，これまで抗原刺激に抢ける上皮細胞と好塩基球の相互作用については検討されていない。

【目的】ダニ抗原刺激に㧍ける, 気道上皮細胞と好塩基球の相互作用による Th2 サイトカイン産生機序について, IL-33の役 割などを中心に明らかにする。

【方法】気道上皮細胞として，IL-33 遺伝子導入により IL-33 放出を生じやすいヒト気管支上皮細胞と，好塩基球として，ヒ 卜慢性骨髄性白血病由来の細胞株 KU812 細胞を用いて, ダニ抗原刺激によるTh2 サイトカイン産生について検討した。

【結果】ダニ抗原で好塩基球を刺激しても Th2 サイトカイン産生は認められなかった。気道上皮細胞をダニ抗原で刺激した 上清で好塩基球を刺激すると IL-5 が産生され，IL-33 の受容体である ST2 受容体阻害薬や抗 IL-33 中和抗体で IL-5 産生は抑 制された。

【結論】ダニ抗原刺激によって気道上皮細胞から放出されたIL-33が，好塩基球を介して IL-5を産生し，アレルギー性炎症 の起点になっている可能性が考えられた。気道上皮細胞と好塩基球の共培養の影響などについても検討する予定である。

第 35 回日本耳鼻咽喉科免疫アレルギー学会

プログラム・抄録集より転用 


\title{
第 35 回日本耳鼻咽喉科免疫アレルギー学会 奨励賞応募演題 S-4
}

\section{IgG4 関連涙腺・唾液腺炎の病変部位における 濾胞ヘルパー $\mathbf{T}$ 細胞の機能的役割}

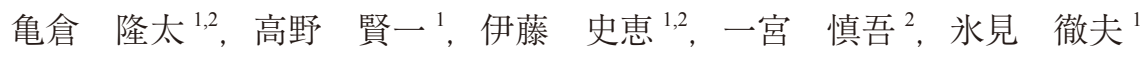 \\ 札幌医科大学耳鼻咽喉科学講座 \\ 2 札幌医科大学フロンティア医学研究所免疫制御医学部門
}

\section{Functional role of follicular helper T cells in lesions of IgG4-related dacryoadenitis and sialadenitis}

\author{
Ryuta Kamekura ${ }^{1,2}$, Kenichi Takano ${ }^{2}$, Fumie Ito ${ }^{1,2}$, Shingo Ichimiya ${ }^{1}$, Tetsuo Himi ${ }^{2}$ \\ ${ }^{1}$ Department of Human Immunology, Research Institute for Frontier Medicine, Sapporo Medical University School of Medicine \\ ${ }^{2}$ Department of Otolaryngology, Sapporo medical University School of Medicine
}

\section{1.はじめに}

IgG4 関連涙腺・垂液腺炎 (IgG4-related dacryoadenitis and sialadenitis; IgG4-DS）は，全身性 IgG4 関連疾患の 1 つ に分類され，ミクリッツ病とも呼ばれる。涙腺・唾液腺の 持続性, 対称性腫脹, 高 IgG4 血症, 局所には著明な IgG4 陽性形質細胞の浸潤を認め, ステロイドによく反応すると いった特徵を持つが，その病態形成のメカニズムは不明な 点が多く残されている。

IgG4-DS の䫟下腺の病理組織では, 正常導管の消失, 多 数の炎症細胞浸潤, 線維化といった所見が認められる。興 味深いことに，浸潤している免疫細胞の中には多数のCD4 陽性 $\mathrm{T}$ 細胞が観察されることから, CD4 陽性 $\mathrm{T}$ 細胞が IgG4-DS の病態形成に関与している可能性がある。

我々が着目した滤胞ヘルパー T (Tfh) 細胞は, CD4 陽性 T細胞サブセットの1つであり, 転写因子はBCL6, 表面 マーカーとして CXCR5 が知られている。IL-4 や IL-21 な どのサイトカインを産生し，リンパ組織での胚中心の形成 や B 細胞の抗体産生を制御する働きを持っている。

今回我々は IgG4-DS，ひいては IgG4 関連疾患の病態形 成に Tfh 細胞による抗体産生の制御機構の異常が関係して いるという仮説を立て，検討を行った。

\section{2. 対象と方法}

対象は手術で得られた IgG4-DS 顎下腺 6 例，コントロー ルとして正常顎下腺 6 例, 鼻ポリープ組織 3 例, 口蓋扁桃 6例，健常者血液 4例である。方法としては，細胞の単離 はFACSAria II セルソーター（BD Biosciences）で，遺伝子 レベルの解析は Real time PCR で, 蛋白レベルの解析はフ
ローサイトメトリー, 免疫染色, ELISAで, 機能解析は Tfh 細胞と B 細胞との共培養の系で行った。

\section{3. 結果}

IgG4-DS 顎下腺組織における Tfh 細胞の局在を免疫染 色で検討したところ，IgG4-DS の顎下腺組織には多くの $\mathrm{CD}^{+}{ }^{+} \mathrm{BCL} 6^{+}$細胞（Tfh 細胞）が浸潤していた。また，顎下 腺組織中の炎症細胞をフローサイトメトリーで解析したと ころ CD4 陽性 T 細胞の約 70\% が CXCR5 陽性，すなわち $\mathrm{Tfh}$ 細胞であった。他のコントロール（正常顎下腺, 鼻ポ リープ，口蓋扁桃，健常者血液）と比較しても明らかにそ の割合が上昇していた。

次に IgG4-DS 顎下腺由来の Tfh 細胞の性質を検討するた めに, セルソーターで Tfh 細胞を単離し, Tfh 細胞関連分 子の遺伝子発現を検討した。コントロールとして，口蓋扁 桃由来の $\mathrm{Tfh}$ 細胞を用いた。結果, IgG4-DS 顎下腺由来の $\mathrm{Tfh}$ 細胞では口蓋扁桃由来の $\mathrm{Tfh}$ 細胞と比較して BCL6, IL-10, CXCL13 の発現増加を認めた。IL-4 と IL-21の遺伝 子発現に関してはコントロールと差は認めなかった。

さらに IgG4-DS 顎下腺由来 $\mathrm{Tfh}$ 細胞の機能解析として, $\mathrm{B}$ 細胞との共培養の系を用いて, IgG4 産生誘導能の検討 を行った。Autogenicの系で, IgG4-DS 顎下腺由来の Tfh 細胞はコントロールの顎下腺組織由来, 口蓋扁桃由来の $\mathrm{Tfh}$ 細胞と比較してより効率的に B 細胞に対して IgG4 の産 生を誘導した。B細胞の違いによる影響を排除するため に, 共通のB 細胞を用いた allogeneic の系でも同様の検討 を行ったが, Autogenicの系と同様の結果が得られた。 


\section{4. 考察}

今回の検討で得られた結果から, IgG4-DS の顎下腺組織 に多く存在する Tfh 細胞は IL-10 や CXCL13 の産生を介し て, B 細胞に対して強力に $\mathrm{IgG} 4$ 抗体の産生を誘導する機 能を持つことが明らかとなった。つまり, IgG4 関連疾患
の病理組織の特徵である, IgG4 陽性形質細胞の増加に Tfh 細胞が関与している可能性があり, IgG4 関連疾患の新規 治療法を開発する上で, 有望な治療ターゲットになり得る と考えられた。 


\section{第 35 回日本耳鼻咽喉科免疫アレルギー学会＼cjkstart奨励賞応募演題Ｓ-5}

\section{SEMA4A の好酸球性副鼻腔炎病態への寄与}

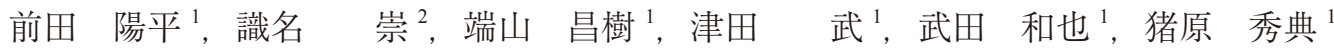

${ }^{1}$ 大阪大学医学系研究科耳鼻咽喉科・頭頸部外科学

2市立池田病院耳鼻いんこう科

【背景・目的】セマフォリンファミリーは神経ガイダンス因子として同定された分子群だが，近年では免疫学的作用も有す ることが明らかとなっている。SEMA4A は classIV セマフォリンであり, 主にT細胞での免疫学的作用が報告されている。 SEMA4A の好酸球性副鼻腔炎（ECRS）病態への関与について検討した。

【方法】ECRS 患者鼻茸㧍よび非好酸球性副鼻腔炎（NECRS）患者鼻茸において SEMA4A の免疫染色を行った。また，血清 中遊離型 SEMA4A の值について ECRS 患者および対照群について ELISA 法で比較した。さらに, SEMA4A 欠損マウス（KO） および野生型マウス（WT）に扔いて脾臟での好酸球細胞数を比較した。続いて骨䯣由来好酸球（BMDEo）を誘導し，その 細胞数㧍よび表面マーカー（Siglec-F）について比較を行った。最後に, 誘導中の BMDEo の増殖についてKO と WT で比較 した。

【結果】ECRS 患者鼻茸免疫染色において SEMA4A は好酸球で高発現していた。また，遊離型 SEMA4A は血清中で対照群よ りも有意に高値であった。脾臟好酸球細胞数については, KOではWTより少なかった。さらに，KO由来の BMDEoは（day0 の細胞数を揃えて誘導した）WT 由来の BMDEo と比較して細胞数が少なく,さらに Siglec-Fの発現が低かった。また, 誘導 中の BMDEoの増殖はWTと比してKOで低かった。

【結論】SEMA4A は好酸球において生存・増殖に有利に働いており，この発現は ECRS の病態において，好酸球性炎症の遷延 に寄与していると考えられた。 


\title{
第 35 回日本耳鼻咽喉科免疫アレルギー学会 奨励賞応募演題 S-6
}

\section{ナローバンドUVB が HeLa 細胞およびTDIアレルギー性鼻炎モデルラットの ヒスタミン $\mathbf{H}_{1}$ 受容体遺伝子発現え進に与える影響}

\author{
藤井 達也 ${ }^{1}$, 北村 嘉章 $^{2}$, 水口 博之 ${ }^{3}$, 福井 裕行 $^{4}$, 武田 憲昭 ${ }^{2}$ \\ JA 高知病院耳鼻咽喉科 \\ 2 徳島大学医学部耳鼻咽喉科 \\ 3 徳島大学薬学部分子情報薬理学 \\ 4 徳島大学大学院ヘルスバイオサイエンス研究部分子難治性疾患学
}

ナローバンドUVB（308～313 nm の狭帯域中波紫外線）光線療法は皮膚の免疫アレルギー疾患である乾癬やアトピー 性皮膚炎の治療に有効である。ナローバンドUVB 光線療法をアレルギー性鼻炎の治療に応用する目的で $310 \mathrm{~nm}$ のナロー バンドUVBを HeLa 細胞に照射し, PMA 刺激によるヒスタミン $\mathrm{H}_{1}$ 受容体遺伝子発現立進の抑制効果を検討したところ, $150 \mathrm{~mJ} / \mathrm{cm}^{2}$ 以下の低用量ではアポトーシスを誘導せず, 用量依存性および波長特異性にヒスタミン $\mathrm{H}_{1}$ 受容体遺伝子発現立 進を抑制した。次にTDIによるアレルギー性鼻炎モデルラットを用いて，ナローバンドUVBの鼻腔への照射がTDIで誘発 する鼻症状および鼻粘膜のヒスタミン $\mathrm{H}_{1}$ 受容体遺伝子発現の亢進を抑制するかについて検討した。モデルラットの鼻腔に $310 \mathrm{~nm}$ のナローバンドUVB を誘発前の 3 日間照射してから TDIによる誘発を行うと，TDIによって誘発された鼻症状およ び鼻粘膜のヒスタミン $\mathrm{H}_{1}$ 受容体遺伝子発現の艺進が有意に抑制された。以上の結果から，ナローバンドUVBの鼻腔照射は 鼻粘膜のヒスタミン $\mathrm{H}_{1}$ 受容体遺伝子発現の立進を抑制して, アレルギー性鼻炎症状を抑制する可能性が示唆され, ナロー バンドUVB 光線療法がアレルギー性鼻炎に臨床応用できる可能性が考えられた。

第35 回日本耳鼻咽喉科免疫アレルギー学会 プログラム・抄録集より転用 


\title{
気道上皮細胞における短鎖脂肪酸による tissue plasminogen activator (t-PA) の産生
}

\author{
意元 義政, 高林 哲司, 坂下 雅文, 徳永 貴広, 成田 憲彦, 藤枝 重治
}

福井大学耳鼻咽喉科・頭頸部外科学

\section{Short chain fatty acids induce tissue plasminogen activator (t-PA) from airway epithelial cells}

\author{
Yoshimasa Imoto, Tetsuji Takabayashi, Masafumi Sakashita, \\ Takahiro Tokunaga, Norihiko Narita, Shigeharu Fujieda
}

Department of Otorhinolaryngology Head \& Neck Surgery, Faculty of Medical Sciences, University of Fukui

\section{1.はじめに}

好酸球性副鼻腔炎は，鼻副鼻腔に鼻茸を伴う慢性炎症性 疾患であり，難治性であり再発率が高いことから，診断基 準と重症度分類が報告され ${ }^{1}$ ，指定難病に認定された。好 酸球性副鼻腔炎の治療には，手術療法と局所および全身入 テロイド投与が必要とされているが, 複数回の手術が必要 なことや，ステロイドの副作用が問題となっており，新規 治療方法が現在渇望されている。鼻茸組織の病理学的特 徵の一つにフィブリンの沈着がある。フィブリンは凝固系 の最終産物であり, 線溶系の plasminにより分解される。 この一連の反応は血管内及び血管外（組織）に扔いて認め られるが，慢性炎症ではフィブリンが組織に蓄積するこ とが病状をさらに遷延化させると考えられている。plasmin の合成には, tissue plasminogen activator (t-PA) と urokinase plasminogen activator (u-PA) が必要であるが, 鼻茸組織では t-PA 産生が上皮細胞に扔いて低下している2。。よって, 気 道上皮細胞からの t-PA 産生を誘導することが可能であれ ば，好酸球性副鼻腔炎に対する新規治療法になりうる可能 性がある。これまで気道上皮細胞に扔ける t-PA の agonist に関する報告は皆無である。一方，血管内皮細胞では vascular endothelial growth factor (VEGF), basic fibroblast growth factor (bFGF) , レチノイン酸, Statinなどの薬剤, そ して酪酸 $\left(\mathrm{C}_{3} \mathrm{H}_{7} \mathrm{COOH}\right)$ が t-PA 産生を誘導することが知ら れている。酪酸は腸管内で腸内細菌叢から食物瀻維を使っ て発䤉産生される短鎖脂肪酸である。短鎖脂肪酸は，腸管 上皮細胞での水や糖の吸収調節, $\mathrm{pH}$ 調節を担うだけでな く, 抗炎症作用や抗腫瘍効果など腸管以外の臟器でも様々 な機能が報告されている3)。本研究では短鎖脂肪酸に注目
し，短鎖脂肪酸により気道上皮細胞からの t-PA 産生の誘 導について検討した。

\section{2. 対象と方法}

短鎖脂肪酸の受容体は，G タンパク質共役結合受容体の G-protein coupled receptor 41 (GPR41）と GPR43 であること が知られている。鼻粘膜上皮細胞にこれらの受容体が存在 しているかを検討するため，手術により採取された正常 銁状突起粘膜と鼻茸組織を用いて, 免疫組織化学を行っ た。次にヒト正常気道上皮細胞 (Normal Human Bronchial Epithelial cells: NHBE cells）を用いて, 酢酸, プロピオン酸, 酪酸，吉草酸，及びカプロン酸を作用させ，NHBE 細胞に おける t-PA 産生について, mRNA及びタンパクで検討し た。mRNAの発現解析には定量 real time PCRで, 培地中 に含まれるt-PAのタンパクについてはELISA で測定した。 NHBE 細胞に扔ける t-PA 産生が GPR41 と GPR43 依存性で あるかを検討するために，Gタンパク質共役結合受容体の ai/oサブユニットの阻害剤である百日咳毒素 (pertussis toxin: PTX）を, $\alpha \mathrm{q} / 11$ サブユニットの阻害薬である YM-254890を 用いて検討した。さらに GPR41 及びGPR43 の small interfering RNA（siRNA）を行い，検討した。

\section{3. 結果}

GPR41 と GPR43 の免疫組織化学の結果, これらの受容 体は, 正常鉤状突起及び鼻茸の上皮細胞に存在しているこ とが分かった。短鎖脂肪酸をNHBE 細胞に作用させると, 酢酸，プロピオン酸，酪酸，そして吉草酸が t-PA 産生を 誘導することが mRNA 発現及び培地中に含まれるタンパ 
クで確認できた。 t-PAを誘導する短鎖脂肪酸のうち, 最も 強く $\mathrm{t}-\mathrm{PA}$ を誘導したのがプロピオン酸 $(10 \mathrm{mM})$ であった。 培地中に含まれる $\mathrm{t}-\mathrm{PA} の$ 活性を調べたところ, NHBE 細 胞から産生, 放出されたt-PA は活性を有していることが 分かった。そして短鎖脂肪酸による NHBE 細胞からの t-PA 産生は, NHBE 細胞への細胞障害を伴わず，かつ培地 中の $\mathrm{pH}$ 変化によらないことが分かった。

$\mathrm{G}$ タンパク質共役結合受容体は， $\alpha$ サブユニットの違い により様々なシグナル伝達を示すことが知られている。 GPR41 は $\alpha$ サブユニットに $\alpha \mathrm{i} / \mathrm{o}$ を, GPR43 は $\alpha \mathrm{i} / \mathrm{o}$ と $\alpha \mathrm{q} / 11$ を有している゙ 。 NHBE 細胞にPTXと YM-254890を前処理 した後に，プロピオン酸を作用させたところ，PTX及び YM-254890 は濃度依存性に NHBE 細胞からの t-PA 産生を 抑制した。さらにGPR41 とGPR43に対する siRNAにより, プロピオン酸刺激による NHBE 細胞からの t-PA 産生が抑 制されることが分かった。これらの結果より短鎖脂肪酸に よる NHBE 細胞からのt-PA 産生誘導が, GPR41 と GPR43 依存性であることが示唆された。

\section{4. 考察}

好酸球性副鼻腔炎の鼻茸は, 好酸球を主体とする多数の 炎症細胞と, 局所の Th2 環境によると考えられている5。 そして好酸球性副鼻腔炎における上皮細胞の t-PA低下の 原因は，Th2サイトカインによるためである ${ }^{2}$ 。近年好酸 球性副鼻腔炎に対する新規治療薬として, 抗 $\operatorname{IgE}$ 抗体など が考案されているが, これらの薬剤は高額であることが 問題である。本研究において短鎖脂肪酸の受容体が鼻粘 膜上皮細胞に存在しており, 気道上皮細胞から短鎖脂肪酸 刺激により t-PA 産生が誘導され, GPR41 と GPR43 依存性 に産生が誘導されることが分かった。これまで気道上皮細 胞における GPR41 と GPR43の報告はなく, 本研究が初め ての検討である。本研究では $10 \mathrm{mM}$ のプロピオン酸が 最も強く $\mathrm{t}-\mathrm{PA}$ 産生を誘導した。短鎖脂肪酸は腸内細菌叢 で合成され，腸管内の短鎖脂肪酸の濃度は高濃度に存在 (〜100 mM) しており, 酢酸, プロピオン酸, 次いで酪酸
の濃度が高いことが知られている6)。しかしながら体内循 環によりこれらの脂肪酸は分解されるため, 血清中の濃度 は低く $(0.5-140 \mu \mathrm{M})^{7)}$, 組織における濃度はさらに低いこ とが予測される。GPR41 と GPR43 は腸管上皮細胞や炎症 細胞にも発現していることが知られており, 各細胞におけ る GPR を活性化するのに必要な短鎖脂肪酸の濃度はいず れも $\mathrm{mM} レ$ レ゙ル゙ある。これは GPRが容易に活性化しな いように各組織で制御されているためであると考えられて いる。本研究の結果でも, NHBE 細胞から t-PA産生を誘 導するために $\mathrm{mM} レ$ レ゙の短鎖脂肪酸が必要であった。こ れらのことから, GPR41 と GPR43の特異的アゴニストが 点鼻投与可能であれば, 好酸球性副鼻腔炎の新規治療薬 として応用できる可能性もあり, 今後検討を行う予定で ある。

\section{参考文献}

1) Tokunaga T, Sakashita M, et al. Novel scoring system and algorithm for classifying chronic rhinosinusitis: the JESREC Study. Allergy. 2015; 70: 995-1003.

2) Takabayashi T, Kato A, et al. Excessive fibrin deposition in nasal polyps caused by fibrinolytic impairment through reduction of tissue plasminogen activator expression. Am J Respir Crit Care Med. 2013; 187(1): 49-57.

3) Sivaprakasam S, Prasad PD, et al. Benefits of short-chain fatty acids and their receptors in inflammation and carcinogenesis. Pharmacol Ther. 2016; 23(16): 30049-3.

4) Le Poul E, Loison C, et al. Functional characterization of human receptors for short chain fatty acids and their role in polymorphonuclear cell activation. J Biol Chem. 2003; 278(28): 25481-9.

5) Van Zele $T$, Claeys $S$, et al. Differentiation of chronic sinus diseases by measurement of inflammatory mediators. Allergy. 2006; 61(11): $1280-9$.

6) Ganapathy V, Thangaraju M, et al. Transporters and receptors for short-chain fatty acids as the molecular link between colonic bacteria and the host. Curr Opin Pharmacol. 2013; 13(6): 869-74.

7) Bergman EN. Energy contributions of volatile fatty acids from the gastrointestinal tract in various species. Physiol Rev. 1990; 70(2): 567-90. 


\title{
HPV 関連中咽頭癌における内因性免疫 APOBEC3 とエストロゲン 一エストロゲン受容体経路を介した発癌機序の検討
}

\author{
加納 亮, 近藤 悟, 高相 裕司, 井本 智子, 上野 貴雄, 吉崎 智一 \\ 金沢大学附属病院耳鼻咽喉科・頭頸部外科
}

【背景】ヒト乳頭腫ウィルス（HPV）による中咽頭癌発癌機序は不明である。当教室では, 中咽頭癌に执いて内因性免疫 APOBEC3（A3）がHPV ゲノムに変異を誘導し発癌に関与することを報告した。しかし，A3を誘導する外的因子は不明であ る。近年，HPV 遺伝子発現マウスにエストロゲン（E2）を投与すると子宮澒癌が誘導され，エストロゲン受容体（ER）の抑 制により発癌が成立しないことが報告された。また，A3 は E2/ER 経路と関連性が強い事も知られ，この経路の重要性が示 唆される。一方，古くから内分泌摚乱物質である E2 擬似物質の食物環境污染が問題となっている。上記から E2 $\cdot \mathrm{E} 2$ 擬似物 質がA3を誘導し，ERを介してHPV 発癌が起こるという仮説を立てた。

【目的】中咽頭癌の HPV 発癌に扔ける A3 と E2/ER 経路の関連性を検討する。

【方法】1）中咽頭癌病理検体を用い, HPV 陽性率, ER, A3 発現量とその関連性を評価した。2）ER 陽性の HPV 陽性中咽頭 癌細胞株に E2・E2 擬似物質を暴露し， A3 と ERの下流シグナル発現を評価した。また, ER 抑制による発現の変化を検討 した。

【結果】1）HPV 陽性中咽頭癌は陰性癌と比し，A3，ERの有意な発現を認めた。2）E2・E2 擬似物質暴露により A3 発現の増 加と下流シグナルの誘導を認めた。

【結論】HPV 関連中咽頭癌の発癌には A3-E2/ER 経路が重要である。

第 35 回日本耳鼻咽喉科免疫アレルギー学会

プログラム・抄録集より転用 